\title{
Composition and Abundance of Benthic Macrofauna of a Tropical Sea-Grass Bed in North Queensland, Australia ${ }^{1}$
}

\author{
David W. Klumpp and Seok Nam Kwak
}

\begin{abstract}
The aims of this study were to characterize the functional composition of benthic macrofauna of a tropical sea-grass bed and to determine temporal variations in abundance of benthic macrofauna in relation to environmental factors such as sea-grass biomass, temperature, salinity, and sediment type. Benthic macrofaunal composition and abundance were investigated by core sampler during April 1999, October 1999, March 2000, and August 2000 at three stations within a sea-grass bed at Cockle Bay in North Queensland, Australia. A total of 110 species of benthic macrofauna was collected. Polychaetes were the most abundant group (37 species; $52 \%$ of total macrofaunal numbers; $47 \%$ of biomass) followed by amphipods ( 27 species; $35 \%$ of total numbers). Decapods were also important, with 28 species contributing $31 \%$ of total macrofaunal biomass. Other miscellaneous groups were tanaids, isopods, and ophiuroids. Most amphipods (65\%) and decapods (90\%) were epifaunal, but polychaetes were equally represented by epifauna and infauna. Temporal variation in both species composition and abundance was large: the peak number of benthic macrofauna occurred in April 1999 and March 2000, and biomass was highest in April 1999. Benthic macrofauna numbers as well as biomass were lowest in August 2000. These temporal patterns of abundance of benthic macrofauna appeared to correlate closely with temporal variation of sea-grass biomass. In addition, the factors of life cycle and predation by common fish species may be indirectly associated with these patterns of macrofaunal abundance.
\end{abstract}

STUdies on FAUNAL-habitat associations in sea-grass beds have shown that these beds are important in providing habitat, shelter, and food for many invertebrates (Lewis 1984, Hutchings et al. 1991, Schneider and Mann 1991, Edgar 1992, Knowles and Bell 1998, Mukai et al. 1999; see review by Williams and Heck 2001). Benthic macrofauna, represented mainly by polychaetes, amphipods, decapods, and mollusks, form a major

\footnotetext{
${ }^{1}$ Manuscript accepted 17 January 2005.

2 Australian Institute of Marine Science, PMB No. 3, Townsville MC QLD 4810, Australia.

${ }^{3}$ Correspondence: Korea Inter-University Institute of Ocean Science, Pukyong University, 599-1 DaeyeonDong, Namgu, Pusan, 608-737, Korea (phone: +8251-620-6290; fax: +82-51-624-5387; e-mail: seoknam@ hotmail.com).
}

Pacific Science (2005), vol. 59, no. 4:541-560

(C) 2005 by University of Hawai'i Press

All rights reserved component of coastal ecosystems and often provide the major trophic linkage between primary producers and fishes (Klumpp et al. 1989). The diverse benthic macrofauna in sea-grass beds occur mainly as epifauna on the leaves of the sea grass and as infauna of surface sediments.

Despite the recognized role of sea-grass beds as habitat for a diverse fauna, and the importance of the benthic macrofauna as a food source of resident fishes in sea-grass beds, there are to our knowledge no published studies on benthic macrofauna in tropical Australian sea-grass beds. In contrast, there have been several studies on temperate sea-grass beds in Australia, looking at interaction between sea-grass structure and macrofaunal assemblages (Edgar 1990, 1992, Mukai et al. 1999), comparison of macrofauna in vegetated and unvegetated areas (Edgar 1994, Edgar et al. 1994), and distribution patterns of mobile epifauna (Collett et al. 1984, Hutchings et al. 1991). Worldwide, a 
few studies have been conducted on benthic macrofauna in tropical sea-grass beds. These include studies on community structure of macrobenthos and the influence of habitat structure in faunal-habitat association in Florida (Young and Young 1977, 1978, Schneider and Mann 1991, Knowles and Bell 1998), distribution of macrofauna and ecological studies of amphipods in Florida (Stoner 1980a,b, 1983, Lewis and Stoner 1983, Lewis 1984), meiofaunal communities in Gazi Bay, Kenya (De Troch et al. 2001), sea-grass diversity and infaunal communities in Thailand (Somerfield et al. 2002), the trophic role of epiphytic periphyton and macroinvertebrate grazers in Philippine sea-grass beds (Klumpp et al. 1992, 1993), and trophic position of gammarid amphipods in a Caribbean seagrass community (Zimmerman 1978). Recent studies on tropical sea-grass beds in Australia have reported distribution and community structure of megabenthos (particularly prawns and crabs) in the Gulf of Carpentaria, Western Australia, and the northern Great Barrier Reef lagoon (Ward and Rainer 1988, Blaber et al. 1993, Long et al. 1995) and juvenile prawn nursery grounds (Coles et al. 1992, Loneragan et al. 1994), and nematode assemblages in tropical Queensland (Fisher 2003).

The sea-grass beds in Cockle Bay, North Queensland, have six or more sea-grass species in scattered patches of small pure stands between 200 and $400 \mathrm{~m}$ wide (Kwak and Klumpp 2004). The abundance and community structure of fishes and decapods inhabiting this sea-grass community displayed wide temporal variation that corresponded with that of sea-grass biomass and abundance of prey (Kwak and Klumpp 2004).

In the study presented here seasonal variation in composition and abundance of benthic macrofauna in sea-grass beds in Cockle Bay were quantified as part of wider investigations on the role of tropical sea-grass beds as potential sources of refuge and food for seagrass fauna. The results of this study are related to our earlier work on the composition, abundance, and trophic relationships of fishes and decapods in the Cockle Bay sea-grass beds (Kwak and Klumpp 2004). Objectives of this study were to determine (1) species composition of benthic macrofauna, (2) functional composition of the fauna, (3) temporal variations (April 1999, October 1999, March 2000, and August 2000) in abundance of benthic macrofauna, and (4) the relationships between benthic macrofaunal abundance and environmental factors such as sea-grass biomass, water temperature, salinity, and sediment type. This study is the first description of benthic macrofauna from a tropical Australian sea-grass bed and thus provides information on a tropical sea-grass ecosystem in the Pacific Ocean, where, compared with the Caribbean, relatively few studies of ecology of benthic macrofauna have been carried out.

\section{MATERIALS AND METHODS}

The study area was located in Cockle Bay on Magnetic Island, about $7 \mathrm{~km}$ off the North Queensland coast (see Figure 1). The area supports a luxuriant and heterogeneous seagrass bed in which the main sea-grass species, by biomass and density, are Cymodocea serrulata, Halodule uninervis, and Halophila ovalis. The sea-grass bed extended in patches for about $6 \mathrm{~km}$ along the shore, and within that three areas dominated by sea grass were chosen as sampling stations (each $\sim 2 \mathrm{~km}$ apart) based on a pilot study in February 1999. The first site (station 1) was located inshore bordering a dense mangrove stand, and major sea-grass species, ranked by biomass, were Cymodocea serrulata (50\%), Halodule uninervis (29\%), and Halophila ovalis (15\%). The second and third sites (stations 2 and 3) were located in the offshore part of the bay in front of the fringing reefs. Cymodocea serrulata (77\%), Halodule uninervis (16\%), and Halophila ovalis (4\%) were the main sea-grass species at station 2 , whereas at station 3 the order was Halodule uninervis (51\%), Cymodocea serrulata (32\%), and Halophila ovalis $(14 \%)$.

The main seasonal difference in the region occurs between the hot/wet period of December-April and the cool/dry months of May-September. Benthic macrofauna were collected from three stations in Cockle Bay in April and October 1999 and March and 


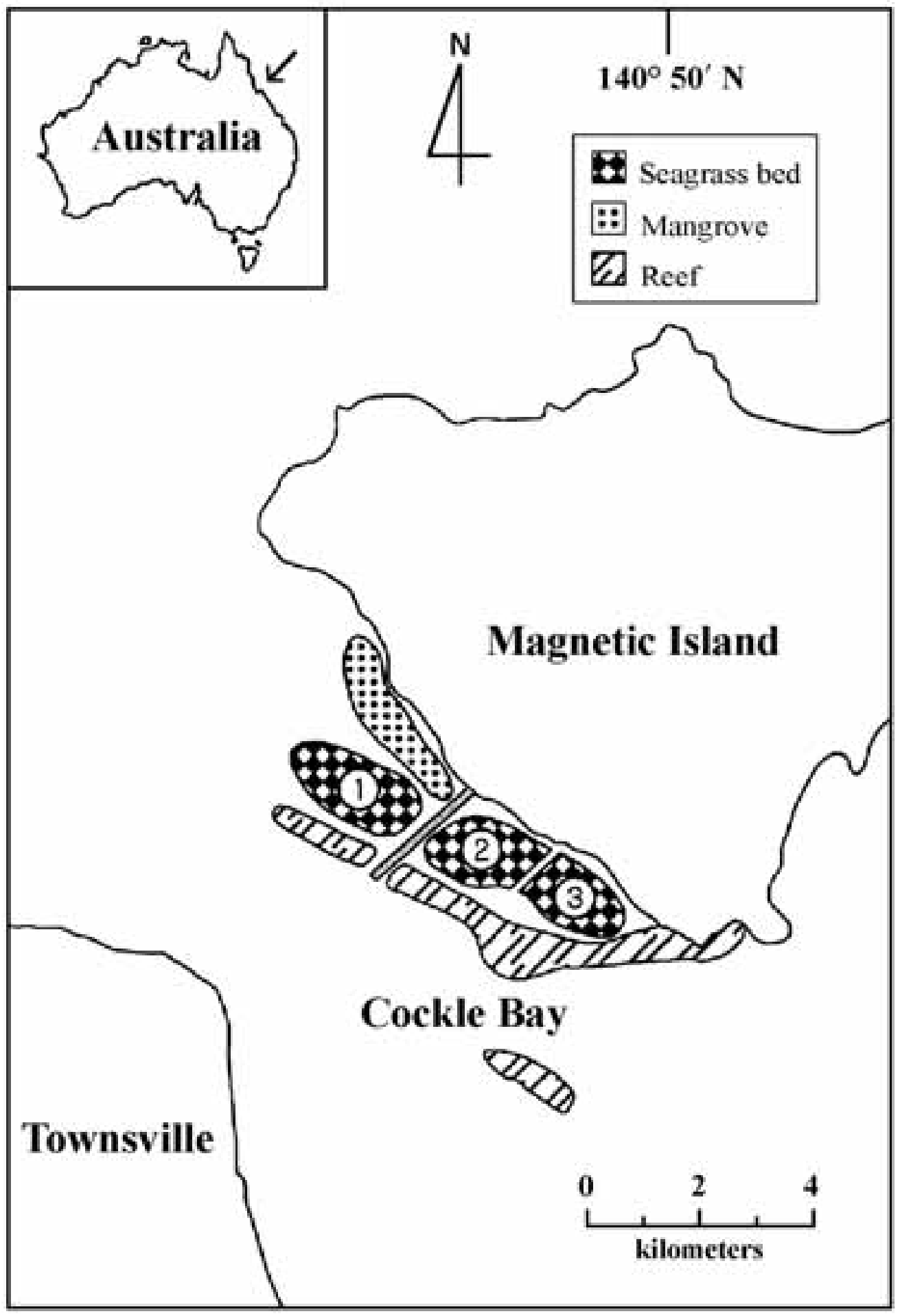

Figure 1. Map of study sites of Cockle Bay, North Queensland. 
August 2000 using hand-held core samplers made of short sections of polyvinyl chloride pipe $(0.1 \mathrm{~m}$ inside diameter). Trials showed that this size of corer collected a significantly greater number of individuals and species richness of fauna per unit area of sediment compared with smaller or larger core samplers $(0.065 \mathrm{~m}$ and $0.15 \mathrm{~m}$ inside diameter; analysis of variance [ANOVA] with log transformation and Kruskal-Wallis one-way analysis, $P<0.05$ ). Core samples were taken to a depth of $20 \mathrm{~mm}$ because pilot investigations showed that $98 \%$ of the benthic macrofauna occurred in the top $5 \mathrm{~mm}$ of sediment. Fifteen replicate core samples were taken in a haphazard fashion within each station on each sampling date.

Samples of macrofauna were preserved in the field using $10 \%$ buffered seawater formalin. In the laboratory, samples were sieved through a $0.5-\mathrm{mm}$ mesh screen, stained with rose Bengal, and transferred to $70 \%$ isopropanol. All animals were sorted into major taxonomic groups, counted, and weighed to the nearest milligram. Organisms were identified to the lowest possible taxon, except for mollusks and echinoderms, which were identified to order level. To characterize the functional composition of the fauna, each macrofaunal species was assigned to a microhabitat category using information from the literature (Bousfield 1973, Rainer and Fitzhardinge 1981) and personal observation (D.W.K. and S.N.K.). Categories were as follows: (1) infaunal tubicolous, (2) infaunal burrower, (3) infaunal commensal (or parasitism), (4) epifaunal domicolous, and (5) epifaunal freeliving. Abundance of animals was reported as both number and biomass (wet weight) per square meter.

Associations between benthic macrofaunal abundance and environmental factors were investigated concurrently with macrofaunal sampling. Temperature (by thermometer) and salinity (by salinometer) were monitored at each station and on each sampling occasion. Sediment from each core was characterized by size fractionation and total organic matter (TOM). TOM was determined on samples dried at $110{ }^{\circ} \mathrm{C}$ for $4 \mathrm{hr}$ and measured as weight loss after combustion at
$550{ }^{\circ} \mathrm{C}$ for $2 \mathrm{hr}$. Sediment grain size was analyzed with a particle size analyzer on gramaliquots dried at $60{ }^{\circ} \mathrm{C}$ for $24 \mathrm{hr}$. Characteristics obtained were median grain size, percentage silt, percentage sand, and percentage gravel. Sea-grass biomass associated with each core was measured. The plants were separated into the above- and belowground parts, dried at $80{ }^{\circ} \mathrm{C}$ for $24 \mathrm{hr}$, and then weighed to the nearest gram.

The benthic macrofaunal data were analyzed to obtain the following community variables. Diversity $\mathrm{H}^{\prime}$ (Shannon and Weaver 1949) was calculated as:

$$
\mathrm{H}^{\prime}=-\sum\left(n_{i} / N\right) \log \left(n_{i} / N\right),
$$

where $n$ is the number of individuals of each $i$ species in a sample and $N$ is the total number of individuals. Evenness J' (Pielou 1969) was calculated as:

$$
\mathrm{J}^{\prime}=\mathrm{H}^{\prime} / \ln \mathrm{S},
$$

where $\mathrm{S}$ is the number of species. A two-way ANOVA with orthogonal design was used to analyze variations in benthic macrofaunal abundance and environmental factors with site and month. Log transformed data were used to satisfy the equal variance assumption of the model. A one-way ANOVA was used to determine variation in the number of macroinvertebrate individuals per sea-grass biomass $\left(\mathrm{g} \mathrm{DW} / \mathrm{m}^{2}\right)$ among the three dominant sea-grass species. Tukey's honestly significant differences test (HSD) was used to compare macrofaunal abundances among the three sea-grass species from each sampling date. The relationships between benthic macrofaunal abundance and environmental factors were analyzed using Pearson's correlation coefficient.

RESULTS

\section{Environmental Factors}

The two-way ANOVAs revealed that the above- and belowground sea-grass biomass varied significantly with month and station (Table 1), with a peak around October 1999 and a sharp decline in March 2000 to August 
TABLE 1

$F$ Values and Levels of Significance for the Two-Way ANOVAs of Environmental Factors $[\log (x+1)]$

\begin{tabular}{|c|c|c|c|c|c|c|c|c|c|c|}
\hline \multirow{2}{*}{$\begin{array}{l}\text { Source of } \\
\text { Variation }\end{array}$} & \multirow[b]{2}{*}{ df } & \multicolumn{2}{|c|}{ Sea-Grass Biomass (g) } & \multirow{2}{*}{$\begin{array}{c}\text { Temperature } \\
\left({ }^{\circ} \mathrm{C}\right)\end{array}$} & \multirow{2}{*}{$\begin{array}{l}\text { Salinity } \\
(\%)\end{array}$} & \multirow{2}{*}{$\begin{array}{c}\text { Grain } \\
\text { Size } \\
(\mathrm{mm})\end{array}$} & \multirow{2}{*}{$\begin{array}{c}\text { TOM } \\
(\%)\end{array}$} & \multirow{2}{*}{$\begin{array}{c}\text { Gravel } \\
(\%)\end{array}$} & \multirow{2}{*}{$\begin{array}{c}\text { Sand } \\
(\%)\end{array}$} & \multirow{2}{*}{$\begin{array}{l}\text { Silt } \\
(\%)\end{array}$} \\
\hline & & Aboveground & Belowground & & & & & & & \\
\hline Month & 3 & $188.7^{* *}$ & $10.78^{*}$ & $10.11^{*}$ & $9.73^{*}$ & 1.45 & 3.92 & 2.43 & 3.33 & 3.21 \\
\hline Station & 2 & $63.5^{\text {** }}$ & $18.5^{*}$ & 4.24 & 5.01 & 2.11 & 4.67 & 3.86 & 4.06 & 3.94 \\
\hline Month $\times$ Station & 6 & $8.45^{*}$ & $6.34^{*}$ & 2.73 & 1.04 & 1.54 & 1.24 & 2.09 & 2.23 & 1.94 \\
\hline
\end{tabular}

${ }^{* *}, P<0.01 ;{ }^{*}, 0.01<P<0.05$.

2000 (Figure 2). There was a small month $\times$ station interaction for sea-grass biomass (Table 1). Although temporal patterns of sea-grass abundance were basically similar across stations, biomass was consistently highest at station 3 , followed by station 2 and station 1. Temperature and salinity varied significantly between months but not among stations (Table 1). Sediment characteristics (percentage TOM, sediment grain size, percentage gravel, percentage sand, and percentage silt) did not vary significantly between months and stations (Table 1).

\section{Faunal Species Composition}

A total of 28,148 individuals of benthic macrofauna representing 110 species (polychaetes, amphipods, decapods, and miscellaneous taxa) was collected from the sea-grass bed in Cockle Bay (Table 2). The major faunal groups ranked by numbers were polychaetes (52\%), amphipods (35\%), and decapods (5\%); however, ranking by biomass, the order was polychaetes (47\%), decapods (31\%), and amphipods (8\%).

Polychaetes were the most dominant group in this tropical sea-grass bed, represented by 37 species of which the most abundant in decreasing order were Capitella capitata, Capitella sp., Prionospio japonicus, Cirriformia tentaculata, Polynoid sp. A, and Laonice sp. Amphipods (27 species) were the next important group, and the most abundant species were Ampithoe caddi, Ericthonius sp. A, Pontogeneia inermis, Elasmopus antennatus, Ericthonius bunteri, and E. brasiliensis. Decapods, which were represented by 28 spe- cies, were important in terms of biomass. The abundant species were Petalomera lateralis, Uca sp., and Thalamita integra. Miscellaneous taxa were tanaids, isopods, ophiuroids, gastropods, bivalves, and echinoids. Seven species of tanaids were present, and Pagurapseudes $\mathrm{sp}$. A was most common. Five species of isopods were recorded, and Cymodoce coronata was the most dominant species throughout the study period. Comparing infaunal and epifaunal components of all benthic macrofauna, most amphipods (58\%) were categorized as epifaunal domicolous and decapods were $90 \%$ epifaunal free-living. Polychaetes were composed of $43 \%$ epifaunal domicolous and $27 \%$ infaunal domicolous and burrower categories.

Relative proportions of some dominant macrofaunal species varied between the three sea-grass species that dominate this sea-grass bed (Figure 3). Dominant benthic macrofauna were defined as those composing $2 \%$ or more of the number of individuals per sea-grass biomass $\left(\mathrm{g} \mathrm{DW} / \mathrm{m}^{2}\right)$. The dominant amphipods Ampithoe caddi, Pontogeneia inermis, and Elasmopus antennatus were most abundant among the sea-grass Cymodocea serrulata; however, members of the genus Ericthoinus were found in greater abundance on Halodule univervis (ANOVA, $F=11.5$, $\mathrm{df}=2, P<0.05)$. The tanaids, Pagurapseudes sp. A, and isopods, Cymodoce coronatus, both epifaunal domicolous, were most numerous on the sea grass Halophila ovalis (ANOVA, $F=23.2, \mathrm{df}=2, P<0.05)$. However, the abundance of dominant polychaetes did not differ between sea-grass species (ANOVA, $F=4.77, \mathrm{df}=2, P>0.05)$. Decapods were 

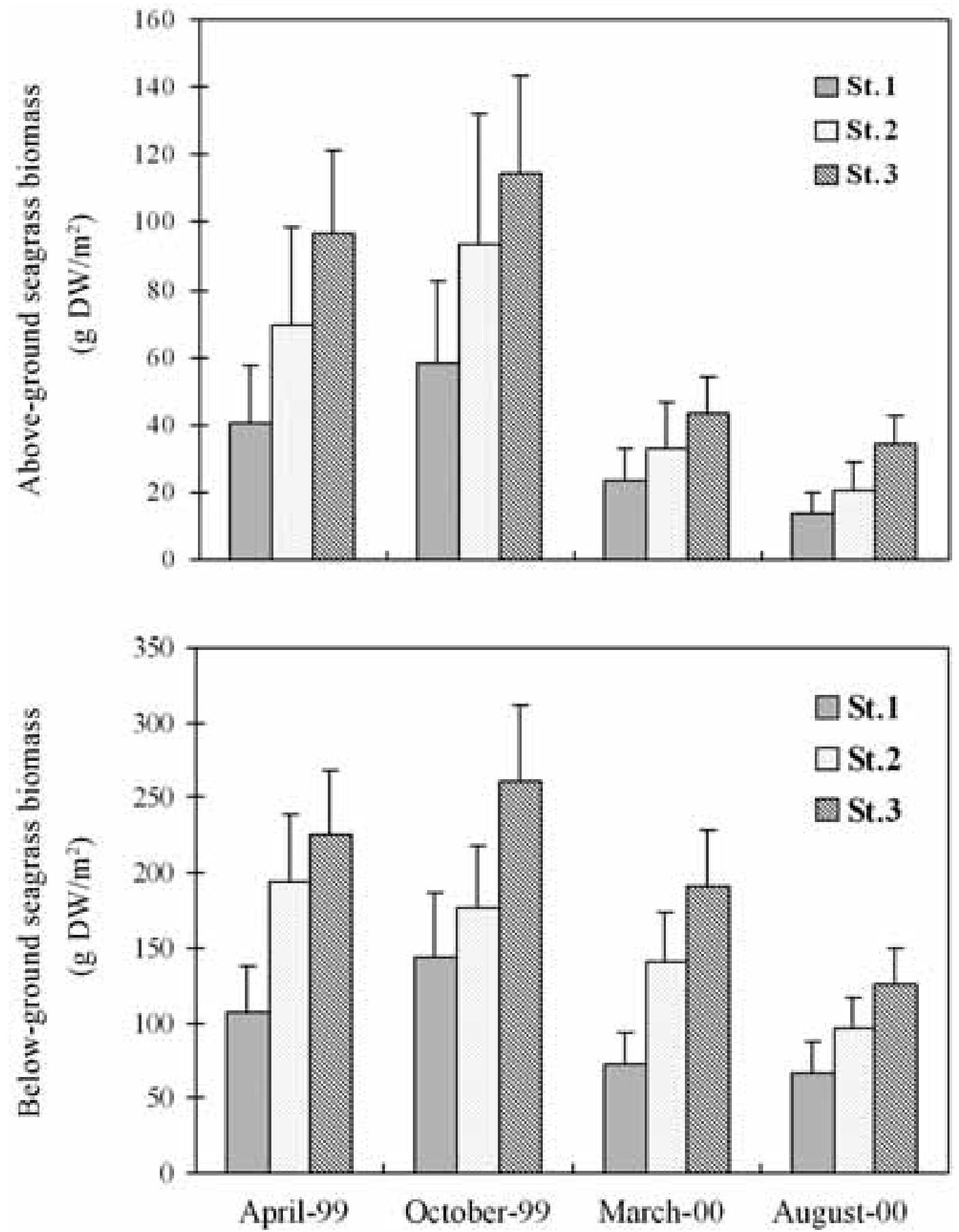

FIGURE 2. Monthly variations of aboveground and belowground sea-grass biomass $( \pm$ SE) at three stations in the seagrass bed in Cockle Bay. 
TABLE 2

Benthic Macrofauna Occurring in the Sea-Grass Beds in Cockle Bay in Order of Decreasing Abundance

\begin{tabular}{|c|c|c|c|c|c|}
\hline Species & $n^{a}$ & $\%$ & $\mathrm{~B}^{b}$ & $\%$ & Habitat Category ${ }^{c}$ \\
\hline \multicolumn{6}{|l|}{ Polychaeta } \\
\hline Capitella capitata & 1,825 & 6.5 & 11.0 & 2.1 & $\mathrm{Ib}$ \\
\hline Capitella sp. & 1,070 & 3.8 & 6.4 & 1.2 & $\mathrm{Ib}$ \\
\hline Prionospio japonicus & 976 & 3.5 & 5.9 & 1.1 & $\mathrm{Ed}$ \\
\hline Cirriformia tentaculata & 900 & 3.2 & 17.1 & 3.2 & Ed \\
\hline Polynoid sp. A & 849 & 3.0 & 22.9 & 4.3 & $\mathrm{Ed}$ \\
\hline Lumbrineris sp. & 637 & 2.3 & 3.2 & 0.6 & $\mathrm{Ib}$ \\
\hline Laonice sp. & 603 & 2.1 & 3.6 & 0.7 & $\mathrm{Ed}$ \\
\hline Notomastus sp. & 535 & 1.9 & 3.2 & 0.6 & $\mathrm{Ib}$ \\
\hline Praxillella sp. & 509 & 1.8 & 7.2 & 1.4 & It \\
\hline Cirriformia sp. & 501 & 1.8 & 9.5 & 1.8 & Ed \\
\hline Syllis sp. A & 492 & 1.7 & 2.8 & 0.5 & $\mathrm{Ed}$ \\
\hline Polynoid sp. B & 484 & 1.7 & 13.1 & 2.5 & $\mathrm{Ed}$ \\
\hline Armandia lanceolata & 467 & 1.7 & 4.7 & 0.9 & $\mathrm{Ib}$ \\
\hline Marphysa sanguinea & 433 & 1.5 & 34.0 & 6.4 & It \\
\hline Platynereis dumerilii & 424 & 1.5 & 4.7 & 0.9 & Ed \\
\hline Onuphis willemoesii & 399 & 1.4 & 4.8 & 0.9 & It \\
\hline Cirratulus sp. & 306 & 1.1 & 5.8 & 1.1 & $\mathrm{Ed}$ \\
\hline Spio sp. & 280 & 1.0 & 1.7 & 0.3 & $\mathrm{Ed}$ \\
\hline Heteromastus sp. & 255 & 0.9 & 1.5 & 0.3 & $\mathrm{Ib}$ \\
\hline Polynoid sp. C & 246 & 0.9 & 6.7 & 1.3 & $\mathrm{Ed}$ \\
\hline Onuphis bolobranchia & 238 & 0.8 & 2.9 & 0.5 & It \\
\hline Haploscoloplos sp. & 229 & 0.8 & 2.3 & 0.4 & It \\
\hline Arabella sp. & 229 & 0.8 & 2.3 & 0.4 & Ic \\
\hline Syllis sp. B & 212 & 0.8 & 1.1 & 0.2 & Ed \\
\hline Platynereis bicanaliculata & 204 & 0.7 & 2.2 & 0.4 & Ed \\
\hline Nereis sp. & 204 & 0.7 & 2.2 & 0.4 & Ed \\
\hline Eunice antennata & 204 & 0.7 & 16.3 & 3.1 & It \\
\hline Maldane sp. & 195 & 0.7 & 3.0 & 0.6 & It \\
\hline Armandia sp. & 136 & 0.5 & 1.4 & 0.3 & $\mathrm{Ib}$ \\
\hline Polyophthalmus sp. & 127 & 0.5 & 1.3 & 0.2 & $\mathrm{Ib}$ \\
\hline Diopatra sugokai & 109 & 0.4 & 1.2 & 0.2 & It \\
\hline Trichobranchus sp. & 102 & 0.4 & 14.3 & 2.7 & $\mathrm{Ib}$ \\
\hline Neanthes sp. & 85 & 0.3 & 0.9 & 0.2 & Ed \\
\hline Eunice australis & 85 & 0.3 & 9.3 & 1.8 & It \\
\hline Syllis sp. C & 76 & 0.3 & 0.4 & 0.1 & $\mathrm{Ed}$ \\
\hline Terebelides sp. & 68 & 0.2 & 14.9 & 2.8 & $\mathrm{Ib}$ \\
\hline Lysidice sp. & 34 & 0.1 & 1.7 & 0.3 & It \\
\hline Subtotal & 14,728 & 52.3 & 247.4 & 46.5 & \\
\hline \multicolumn{6}{|l|}{ Amphipoda } \\
\hline Ampithoe caddi & 2,852 & 10.1 & 24.2 & 4.6 & Ed \\
\hline Ericthonius sp. A & 1,566 & 5.6 & 3.4 & 0.6 & Ed \\
\hline Pontogeneia inermis & 1,290 & 4.6 & 1.9 & 0.4 & $\mathrm{Ed}$ \\
\hline Elasmopus antennatus & 772 & 2.7 & 0.9 & 0.2 & $\mathrm{Ed}$ \\
\hline Ericthonius bunteri & 603 & 2.1 & 1.3 & 0.2 & $\mathrm{Ed}$ \\
\hline Ericthonius brasiliensis & 598 & 2.1 & 1.3 & 0.3 & $\mathrm{Ed}$ \\
\hline Podocerus spongicolus & 450 & 1.6 & 1.3 & 0.2 & $\mathrm{Ed}$ \\
\hline Paracalliope sp. A & 315 & 1.1 & 1.1 & 0.2 & $\mathrm{Ib}$ \\
\hline Ampelisca typica & 246 & 0.9 & 1.1 & 0.2 & It \\
\hline Probarpinia sp. & 178 & 0.6 & 0.5 & 0.1 & It \\
\hline Elasmopus rapax & 161 & 0.6 & 0.2 & 0.0 & $\mathrm{Ed}$ \\
\hline Phoxocephalus sp. & 153 & 0.5 & 0.4 & 0.1 & It \\
\hline Lysianassa sp. & 144 & 0.5 & 0.3 & 0.1 & It \\
\hline Ericthonius sp. B & 118 & 0.4 & 0.3 & 0.0 & Ed \\
\hline Ampelisca milleri & 110 & 0.4 & 0.5 & 0.1 & It \\
\hline Leucotboe sp. A & 93 & 0.3 & 1.3 & 0.2 & Ic \\
\hline
\end{tabular}


TABLE 2 (continued)

\begin{tabular}{|c|c|c|c|c|c|}
\hline Species & $n^{a}$ & $\%$ & $\mathrm{~B}^{b}$ & $\%$ & Habitat Category ${ }^{c}$ \\
\hline Elasmopus sp. B & 68 & 0.2 & 0.1 & 0.0 & $\mathrm{Ed}$ \\
\hline Ampitboe sp. A & 42 & 0.1 & 0.4 & 0.1 & Ed \\
\hline Elasmopus sp. A & 42 & 0.1 & 0.1 & 0.0 & Ed \\
\hline Ampelisca sp. & 25 & 0.1 & 0.1 & 0.0 & It \\
\hline Hyale frequens & 25 & 0.1 & 0.1 & 0.0 & Ed \\
\hline Dexamine sp. & 17 & 0.1 & 0.0 & 0.0 & $\mathrm{Ef}$ \\
\hline Dexamine spinosa & 17 & 0.1 & 0.0 & 0.0 & Ef \\
\hline Paracalliope sp. B & 16 & 0.1 & 0.1 & 0.0 & $\mathrm{Ib}$ \\
\hline Gitanopsis vilordes & 16 & 0.1 & 0.0 & 0.0 & Ed \\
\hline Anisogammarus pugettensis & 8 & 0.0 & 0.1 & 0.0 & Ed \\
\hline Leucothoe sp. B & 8 & 0.0 & 0.1 & 0.0 & Ic \\
\hline Subtotal & 9,933 & 35.3 & 41.1 & 7.7 & \\
\hline \multicolumn{6}{|l|}{ Decapoda } \\
\hline Petalomera lateralis & 212 & 0.8 & 3.6 & 0.7 & Ef \\
\hline Uca sp. & 144 & 0.5 & 1.9 & 0.4 & $\mathrm{Ib}$ \\
\hline Thalamita integra & 136 & 0.5 & 6.1 & 1.1 & Ef \\
\hline Alpheus sp. A & 110 & 0.4 & 9.9 & 1.9 & $\mathrm{Ib}$ \\
\hline Clibanarius sp. & 109 & 0.4 & 7.5 & 1.4 & Ef \\
\hline Paratya australiensis & 85 & 0.3 & 1.7 & 0.3 & $\mathrm{Ef}$ \\
\hline Alpheus sp. B & 76 & 0.3 & 6.9 & 1.3 & $\mathrm{Ib}$ \\
\hline Clibanarius taeniatus & 76 & 0.3 & 5.1 & 1.0 & $\mathrm{Ef}$ \\
\hline Thalamita intermedia & 59 & 0.2 & 2.7 & 0.5 & Ef \\
\hline Diogenes sp. & 50 & 0.2 & 3.4 & 0.6 & Ef \\
\hline Paguristes sp. & 34 & 0.1 & 2.3 & 0.4 & $\mathrm{Ef}$ \\
\hline Rbynchocinetes sp. A & 25 & 0.1 & 0.2 & 0.0 & Ef \\
\hline Atypopenaeus stenodactylus & 17 & 0.1 & 1.1 & 0.2 & $\mathrm{Ef}$ \\
\hline Palaemonetes sp. & 17 & 0.1 & 0.2 & 0.0 & Ef \\
\hline Brachycarpus sp. & 17 & 0.1 & 0.2 & 0.0 & Ef \\
\hline Latreutes sp. A & 17 & 0.1 & 0.2 & 0.0 & $\mathrm{Ef}$ \\
\hline Gnathophylloides sp. & 17 & 0.1 & 0.1 & 0.0 & Ef \\
\hline Leucoisa sp. & 17 & 0.1 & 0.5 & 0.1 & Ef \\
\hline Rhynchocinetes sp. B & 8 & 0.0 & 0.1 & 0.0 & Ef \\
\hline Latreutes sp. B & 8 & 0.0 & 0.1 & 0.0 & $\mathrm{Ef}$ \\
\hline Calcinus lateus & 8 & 0.0 & 0.5 & 0.1 & Ef \\
\hline Portunus pelagicus & 8 & 0.0 & 0.4 & 0.1 & $\mathrm{Ef}$ \\
\hline Thalamita cooperi & 8 & 0.0 & 0.4 & 0.1 & Ef \\
\hline Huenia proteus & 8 & 0.0 & 99.2 & 18.7 & Ef \\
\hline Naxia aries & 8 & 0.0 & 2.9 & 0.5 & $\mathrm{Ef}$ \\
\hline Hemigrapsus sanguineus & 8 & 0.0 & 0.1 & 0.0 & Ef \\
\hline Daldorfia sp. & 8 & 0.0 & 5.2 & 1.0 & Ef \\
\hline Subtotal & 1,290 & 4.6 & 162.2 & 30.5 & \\
\hline \multicolumn{6}{|l|}{ Miscellaneous taxa } \\
\hline \multicolumn{6}{|l|}{ Tanaidacea } \\
\hline Pagurapseudes sp. A & 432 & 1.5 & 2.3 & 0.4 & Ed \\
\hline Pagurapseudes sp. B & 203 & 0.7 & 1.1 & 0.2 & Ed \\
\hline Bilobatus sp. & 178 & 0.6 & 1.9 & 0.4 & Ed \\
\hline Bilobatus crenulatus & 170 & 0.6 & 1.8 & 0.3 & $\mathrm{Ed}$ \\
\hline Leptochelia sp. & 68 & 0.2 & 0.3 & 0.1 & Ed \\
\hline Pagurapseudes sp. C & 51 & 0.2 & 0.3 & 0.1 & $\mathrm{Ed}$ \\
\hline Leptochelia dubia & 25 & 0.1 & 0.1 & 0.0 & Ed \\
\hline \multicolumn{6}{|l|}{ Isopoda } \\
\hline Cymodoce coronata & 424 & 1.5 & 14.1 & 2.7 & Ed \\
\hline Paranthura elegans & 119 & 0.4 & 1.2 & 0.2 & $\mathrm{Ed}$ \\
\hline Cirolana sp. A & 51 & 0.2 & 0.9 & 0.2 & Ed \\
\hline Cymodoce aculeata & 8 & 0.0 & 0.3 & 0.1 & $\mathrm{Ed}$ \\
\hline Cirolana sp. B & 8 & 0.0 & 0.1 & 0.0 & Ed \\
\hline
\end{tabular}


TABLE 2 (continued)

\begin{tabular}{lrrrrc}
\hline \hline Species & \multicolumn{1}{c}{$n^{a}$} & $\%$ & $\mathrm{~B}^{b}$ & $\%$ & Habitat Category $^{c}$ \\
\hline Ophiuroidea & 244 & 0.9 & 4.9 & 0.9 & Ef \\
Gastropoda & 81 & 0.3 & 21.9 & 4.1 & Ef \\
Bivalvia & 76 & 0.3 & 16.7 & 3.1 & $\mathrm{Ib}$ \\
Echinoidea & 59 & 0.2 & 13.0 & 2.4 & $\mathrm{Ef}$ \\
$\quad$ Subtotal & 2,197 & 7.8 & 80.7 & 15.2 & \\
Total & 28,148 & 100.0 & 531.4 & 100.0 & \\
\hline
\end{tabular}

Note: Values are summed across all samples for all stations at all times.

${ }^{a} n$, total number of individuals.

${ }^{b} \mathrm{~B}$, total biomass.

${ }^{c}$ Habitat category: It, infaunal tubicolous; Ib, infaunal burrower, Ic, infaunal conmmensal (or parasitism); Ed, epifaunal domicolous; Ef, epifaunal free-living.

not dominant in terms of number of individuals on any particular sea-grass species.

\section{Temporal and Site Variations in Faunal Abundance}

Using two-way ANOVAs, the mean number of benthic macrofaunal species varied with month, but there was no marked variation across station (Table 3, Figure 4). Numbers of individuals varied significantly with both month and station (Table 3) and were generally higher at station 3 except in March 2000. There was a slight month $\times$ station interaction for numbers of individuals (Table 3). Highest numbers of benthic macrofauna occurred in April 1999 and March 2000 except at station 3, and lowest numbers occurred in August 2000. There were no differences in macrofaunal biomass between month and station (Table 3). Faunal biomass displayed a similar pattern at each station, except for the peak at station 3 in April 1999 when a few relatively large decapods were present. All three stations had similar values of diversity and evenness regardless of month, suggesting that the number and relative abundances of benthic macrofauna were similar over study periods.

Abundance of common groups of benthic macrofauna in Cockle Bay showed considerable temporal variation (Figure 5). The two-way ANOVAs revealed that number of polychaete individuals differed significantly between months (Table 3). Polychaetes were few in April 1999, peaked in October 1999 at about 2,000 individuals per square meter, and then decreased in March 2000. Peak polychaete biomass was in October 1999 due to many larger individuals in this period (Table 3 ); however, number and biomass did not vary with stations (Table 3). Number of individuals of amphipods also peaked in April 1999 due to increased Ampithoe caddi and Pontogeneia inermis and in March 2000 when there were increased numbers of Ericthonius sp. A and Elasmopus antennatus. Abundance of amphipods varied with site, being generally higher at station 3 (Table 3). High biomass of amphipods occurred in October 1999 when the community was dominated by relatively large $A$. caddi. In the case of decapods, number of individuals was highest at station 1 in April 1999; however, biomass was high at station 3 in April 1999 due to presence of Huenia proteus (Table 3).

Sea-grass biomass variation corresponded closely with temporal variation in the abundance of benthic macrofauna during the study period (Figure 6). For example, number of individuals of polychaetes $\left(\mathrm{r}^{2}=0.79\right.$, $P<0.01)$ was strongly correlated with belowground sea-grass biomass. Numbers and biomass of amphipods $\left(r^{2}=0.70, r^{2}=0.68\right.$, $P<0.01)$ and numbers of decapods $\left(\mathrm{r}^{2}=\right.$ $0.61, P<0.01)$ were correlated with aboveground sea-grass biomass, whereas those of tanaids $\left(\mathrm{r}^{2}=0.62, P<0.01\right)$ were correlated negatively with aboveground sea-grass biomass. Polychaete abundance $\left(\mathrm{r}^{2}=0.44, P<\right.$ 


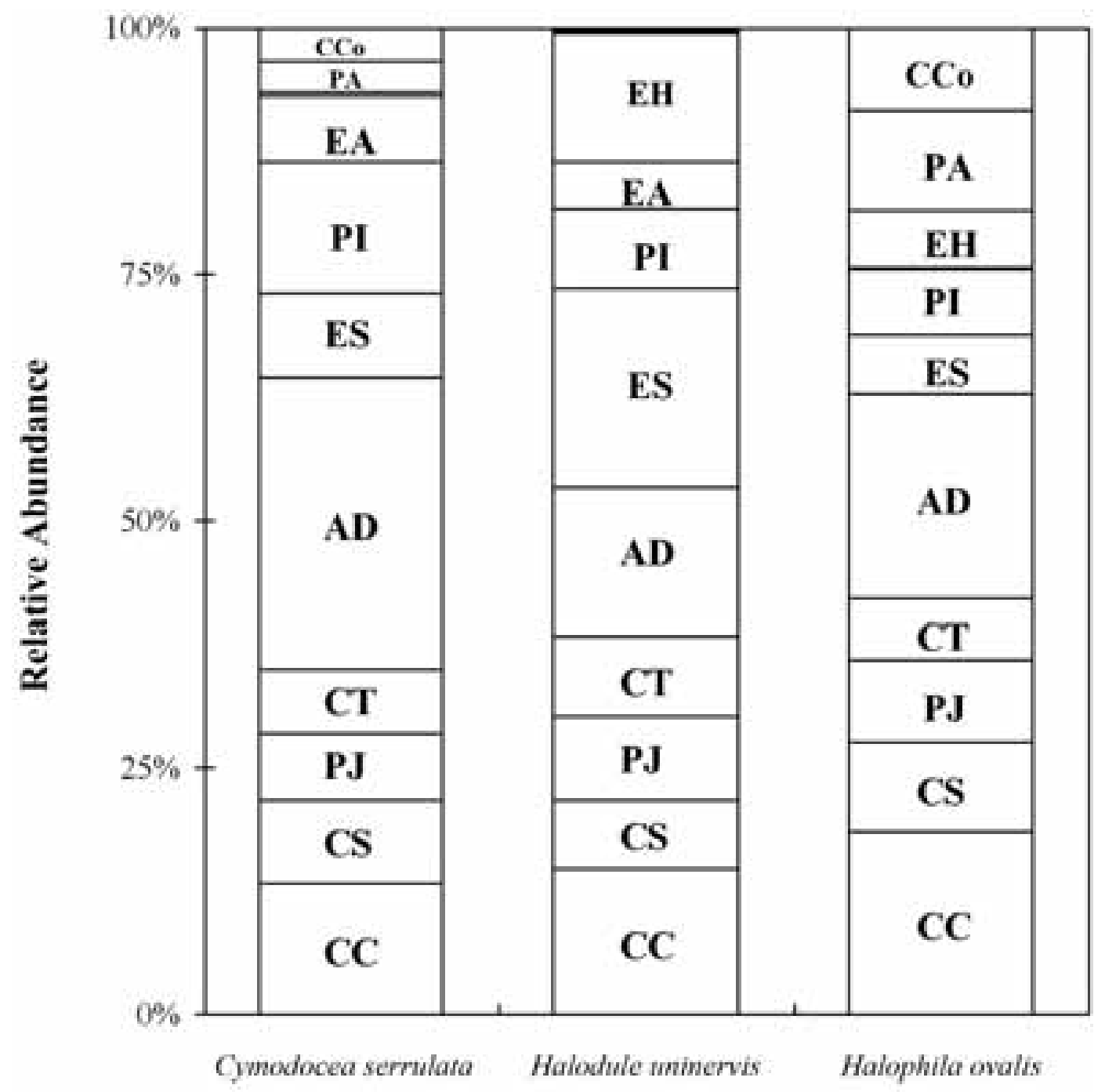

\section{Seagrass species}

FIgURE 3. Relative abundance of dominant benthic macrofauna occurring on the three dominant sea-grass species in Cockle Bay. Dominant macrofauna are those comprising $2 \%$ or more of the number of individuals per sea-grass biomass $\left(\mathrm{g} \mathrm{DW} / \mathrm{m}^{2}\right)$. Data are summed across all three stations and sampling times. CC, Capitella capitata; CS, Capitella sp.; PJ, Prionospio japonicus; CT, Cirriformia tentaculata; AD, Ampithoe caddi; ES, Ericthonius sp. A; PI, Pontogeneia inermis; EA, Elasmopus antennatus; EH, Ericthonius hunteri; PA, Pagurapseudes sp. A; CCo, Cymodoce coronata.

$0.05)$ and above- and belowground sea-grass biomass $\left(\mathrm{r}^{2}=0.35, \quad \mathrm{r}^{2}=0.41, \quad P<0.05\right)$ were both correlated with temperature and salinity. Benthic macrofaunal abundances were not significantly correlated with sediment characteristics (percentage TOM, sediment grain size, percentage gravel, percentage sand, and percentage silt). 


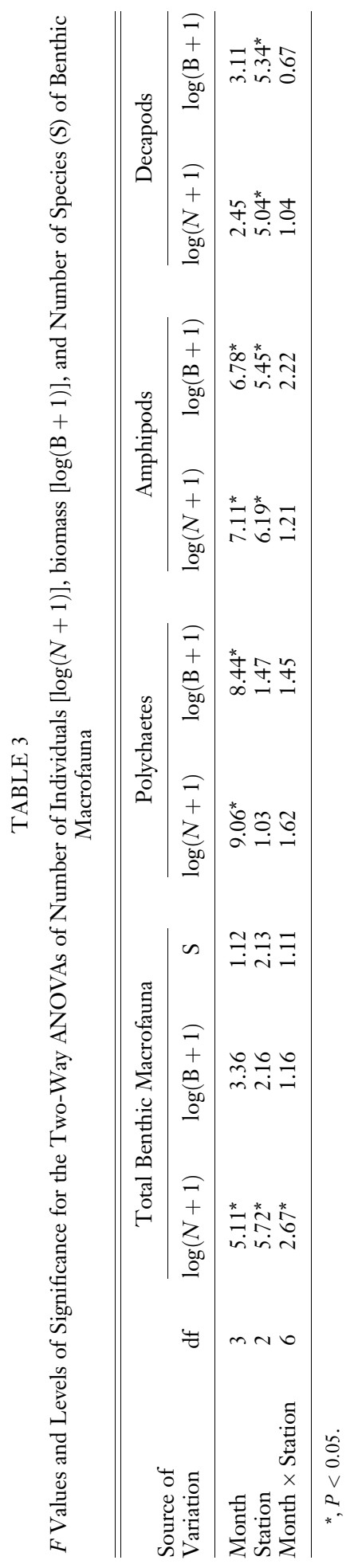



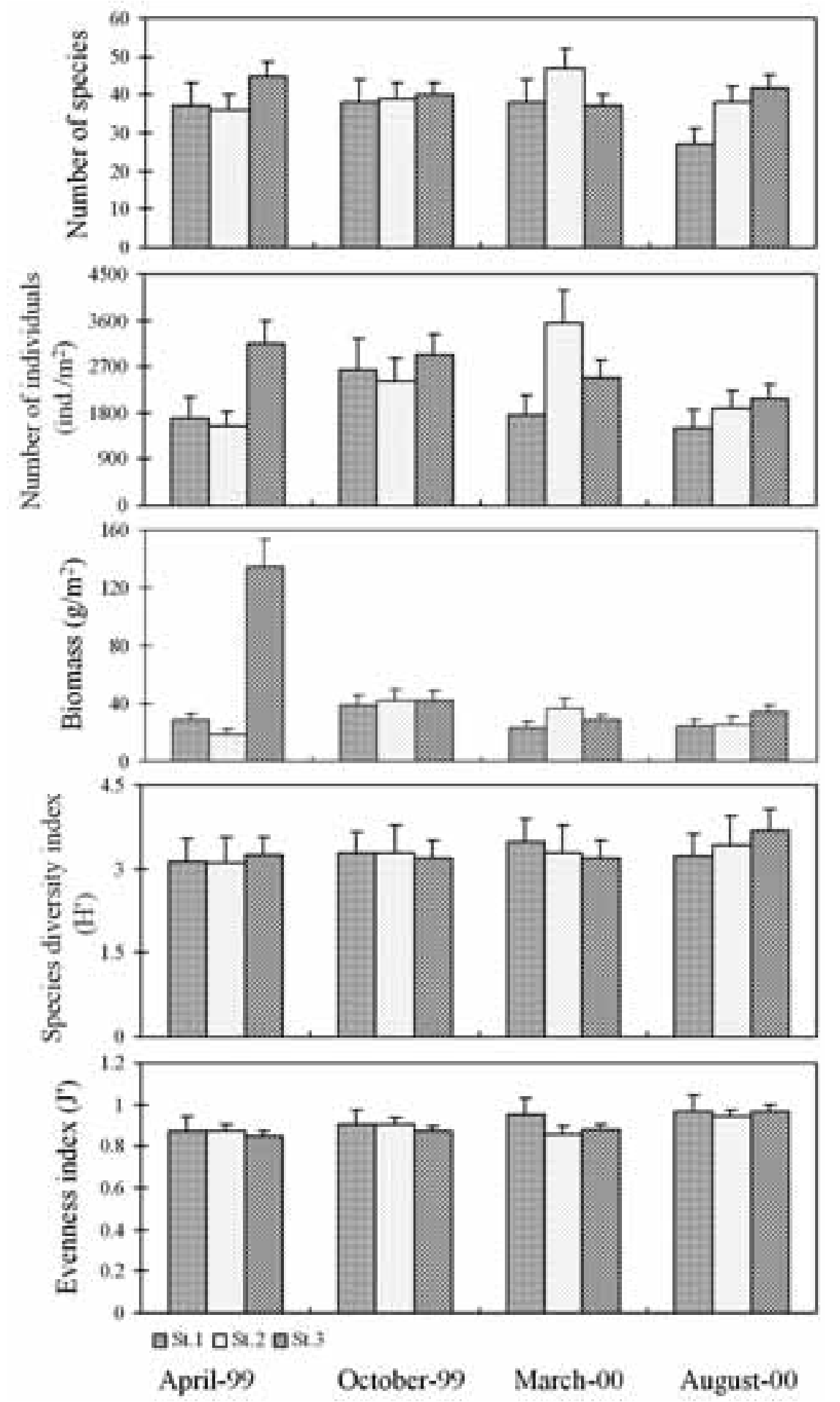

FIGURE 4. Monthly variation in number of species, number of individuals, biomass, species diversity index, and evenness index of benthic macrofauna (per square meter, \pm SE) at three stations in the sea-grass bed in Cockle Bay. 

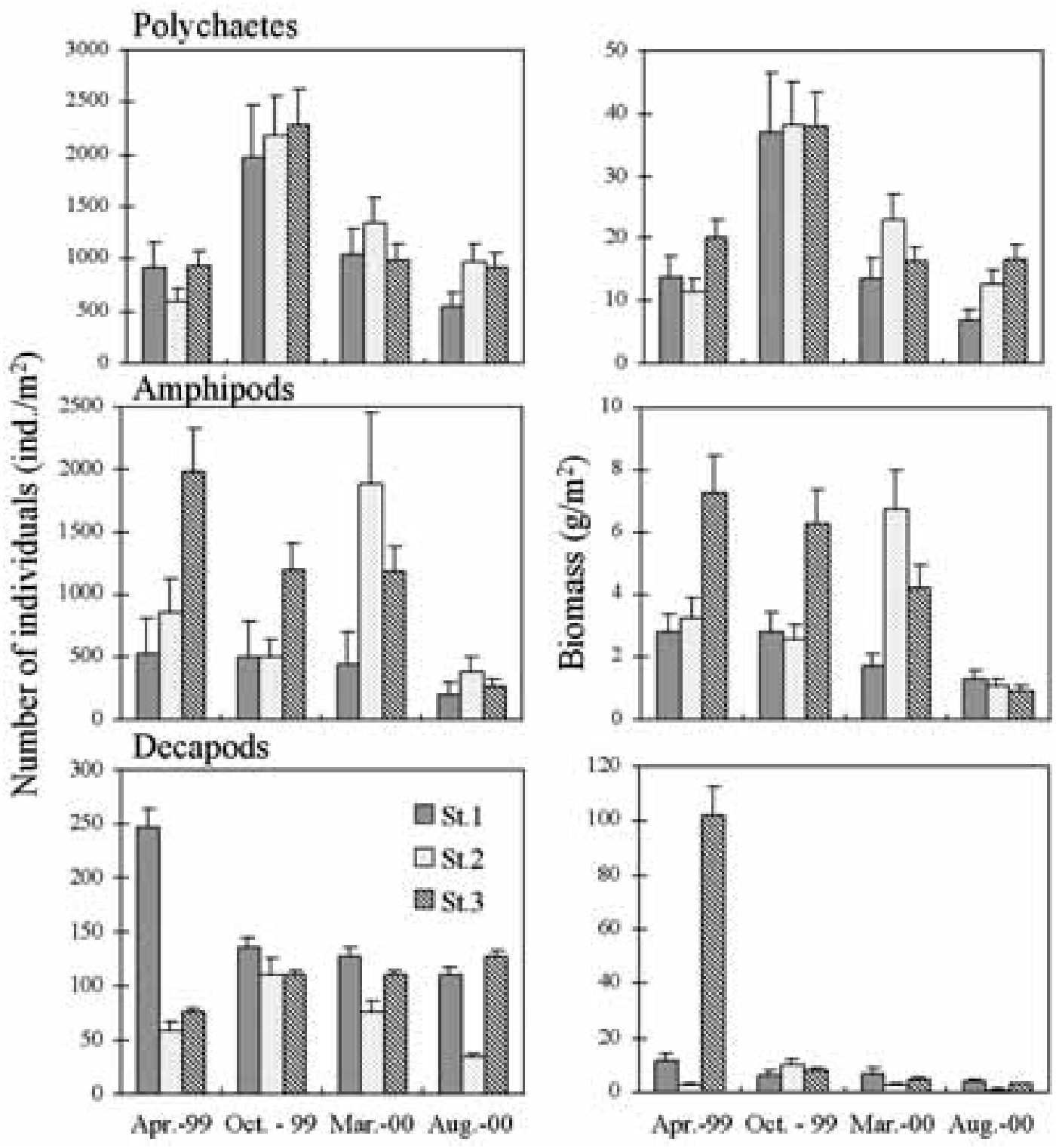

FIGURE 5. Monthly variations in number of individuals and biomass of dominant benthic macrofauna $( \pm \mathrm{SE})$ at three stations in the sea-grass bed in Cockle Bay.

\section{DISCUSSION}

\section{Faunal Species Composition}

Numerically dominant macrofaunal groups in sediment cores taken from sea-grass beds in Cockle Bay, North Queensland, were polychaetes (52\%), amphipods (35\%), and de- capods (5\%). Some or all of these groups also dominated sea-grass beds in other parts of Australia and overseas. For example, polychaetes and decapods were the dominant groups in temperate Australian sea-grass beds along the New South Wales coast (Collett et al. 1984); polychaetes, gammarid amphi- 

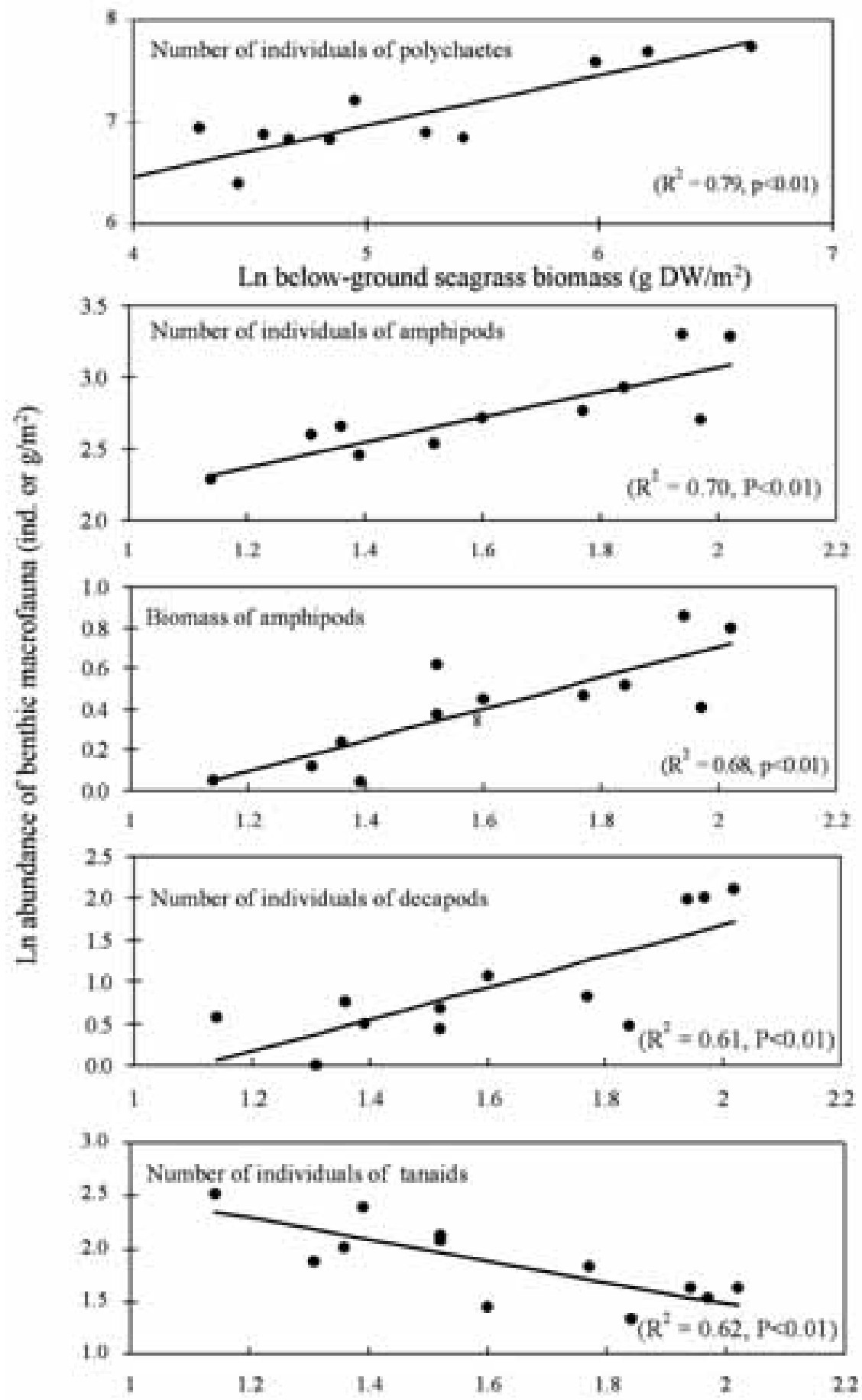

$\mathrm{Ln}$ above-ground scagrass biomass ( $\mathrm{g} \mathrm{DW} / \mathrm{m}^{2}$ )

FIgURE 6. Relationships between abundance of benthic macrofauna and sea-grass biomass at three stations in the seagrass bed in Cockle Bay. 
pods, and mollusks in Princess Royal Harbour Albany, Western Australia (Hutchings et al. 1991); and polychaetes and amphipods in Western Port, Victoria, and Thomas Bay, Rottnest Island, Western Australia (Edgar et al. 1994, Mukai et al. 1999). In tropical American sea-grass beds the dominant groups were gammarid amphipods (45\%), polychaetes $(27 \%)$, and decapods $(5 \%)$ in Apalachee Bay (Lewis and Stoner 1983) and amphipods, isopods, and tanaids in Tampa Bay, Florida (Knowles and Bell 1998). Similar groups dominated in temperate sea-grass beds of North America (Young et al. 1976, Young and Young 1977, 1978, Stoner 1983). In terms of biomass, bivalve and gastropod mollusks have been found to be dominant in some temperate Australian sea-grass beds (Hutchings 1982, Collett et al. 1984).

The taxonomic composition of amphipod and polychaete faunas of sea-grass beds from around the world also displays similarities across a wide geographic area. In Cockle Bay, the most common amphipods were $\mathrm{Am}$ pithoe, Ericthonius, Pontogeneia, and Elasmopus, and common polychaetes were Capitella, Platynereis, Cirriformia, and Notomastus. Ericthonius and Platynereis also dominated in Seven Mile Beach (Edgar 1990, 1992) and Rottnest Island, Western Australia (Mukai et al. 1999); Apalachee Bay, Florida (Lewis 1984); and Kwangyang Bay, Korea (Kwak 1997). In addition, Ampithoe and Capitella were also dominant in tropical American sea-grass beds (Stoner 1983, Lewis 1984, Knowles and Bell 1998). Thus polychaetes, amphipods, decapods, and in some cases mollusks are consistently the dominant macrofaunal groups in sea-grass beds regardless of location and climate.

It is interesting that these same groups of macrofauna that dominate in sea-grass beds tend also to dominate the biomass of mobile macroinvertebrate communities inhabiting a wide range of subtidal shallow habitats including rocky reef, mangrove, seaweeds, and soft-sediment communities (see Bertness et al. 2001). For example, polychaetes and crustaceans were dominant in the Venice lagoon populated by sea grasses and seaweeds, and similarly in the mangroves of Rookery
Bay, Florida (Sheridan 1997, Sfriso et al. 2001). Edgar and Barrett (2002) demonstrated that 155 crustacean species (principally amphipods) and 103 polychaete species dominated the fauna in soft substrates in Tasmanian estuaries. In sea-grass beds, these groups may dominate in part because they provide functional advantages to the sea-grass bed, such as promoted sediment aeration by burrowing activity and enhanced productivity of sea grass through recycling of nutrients and grazing controls on epiphytes (Nelson 1980, Orth et al. 1984, Hutchings et al. 1991, Valentine et al. 1994, 1997, Knowles and Bell 1998). The amount of light available for photosynthesis is generally believed to be the major factor for epiphytes outcompeting sea grasses (Mazzella and Alberte 1986), and the effect of the removal of heavy epiphyte loads by grazing macroinvertebrates is to reduce drag and increase sea-grass flexibility (Heijs 1985).

Most macrofaunal species associated with sea grass in Cockle Bay were equally abundant on different sea-grass species that dominated across the three stations. However, the relative proportion of dominant amphipods (Ampithoe caddi, Elasmopus antennatus, Ericthonius sp. A) differed among the three most abundant sea-grass species (Cymodocea serrulata, Halodule uninervis, and Halophila ovalis) of Cockle Bay. These were most abundant among the wide-bladed sea grass Cymodocea serrulata, except Ericthionus with elongated body, which were in greater abundance on thin-bladed Halodule uninervis. Tanaids and isopods with stout bodies were most numerous on the wide-bladed sea grass Halophila ovalis. Other studies have shown similar patterns of variable faunal abundance in mixed sea-grass communities. For example, Lewis (1984) found a greater abundance of caprellid amphipods Luconacis incerta and isopods Erichsonella filiformis with elongated bodies on thin-bladed sea grass Halodule wrightii compared with wide-bladed sea grass Thalassia testudinum; however, stout-bodied species (e.g., Elasmopus, Hippolyte) were more numerous on wide T. testudinum blades.

The benthic macrofauna in Cockle Bay (110 species, 28,148 individuals per square 
meter) has similar diversity but considerably higher densities compared with other seagrass beds in temperate and tropical areas. For example, a study of the fauna of Posidonia australis beds along the New South Wales coast revealed considerable variation between sites in terms of the number of species present (39-134) and the density of individuals (599-4,866 individuals per square meter) (Collett et al. 1984). Lower density (1,7972,327 individuals per square meter) of macrofauna was reported in Princess Royal Harbour, Albany, Western Australia (Hutchings et al. 1991), and in Apalachee Bay, Florida (80 species, 654 individuals per square meter in Apalachee Bay [Lewis and Stoner 1983]).

\section{Temporal and Site Variations in Faunal Abundance}

Abundances of epifauna and infauna in seagrass meadows are often correlated with above- and/or belowground sea-grass biomass (see review by Orth et al. 1984). The temporal pattern of abundance of benthic macrofauna in the sea-grass beds of Cockle Bay correlated with temporal variations in sea-grass biomass. From the data available it is not possible to determine whether variation in sea-grass biomass, directly or indirectly, determined these changes in faunal abundance in Cockle Bay, or whether faunal activities had an effect on the sea-grass biomass. However, there is evidence for both types of interaction occurring in sea-grass beds (Orth et al. 1984, Valentine et al. 1994, 1997, Duarte et al. 1997).

Sea-grass biomass in Cockle Bay reached a peak in October 1999, when light and water temperature are increasing, and remained high over summer, then decreased to a minimum in the period from March 2000 to August 2000 in midwinter (Kwak and Klumpp 2004). This decrease in sea-grass biomass also coincided with the disturbance of heavy winds and rainfall brought by a cyclone in February 2000. Numbers of polychaetes in Cockle Bay were high during periods when belowground sea-grass biomass was high. The thick, tough underground mat of roots and rhizomes produced by Halodule and $C y$ modocea in Cockle Bay seems to provide polychaetes and other infauna with an effective refuge from predators, especially invertebrates. Indeed, the importance of rhizomes in protecting infauna from crab predators has been suggested (Orth et al. 1984). As well, sea-grass diversity can dictate the infaunal community structure (e.g., of free-living nematodes [Somerfield et al. 2002]). Alternatively, burrowing activity of certain infauna may assist in colonization, growth, and persistence of certain sea-grass species (Valentine et al. 1994). For example, Halophila ovalis tends to colonize gaps created by burrowing infauna (Duarte et al. 1997). There was no evidence in the study reported here of any particular sea-grass species correlating with the abundance of any burrowing macrofaunal groups.

Amphipod abundance in particular was positively correlated with aboveground seagrass biomass. This is in general agreement with other studies of tropical sea-grass beds of Florida and the Caribbean (Zimmerman 1978, Lewis and Stoner 1983, Knowles and Bell 1998). Amphipods in Cockle Bay during April 1999 and March 2000 were mainly represented by detritivores and herbivores, probably in response to the increased abundance of the erect epiphytic algal layer on sea-grass fronds at those times (D.W.K. and S.N.K., pers. obs.). This layer of algae constitutes a primary food resource supplementing sea-grass frond material for gammarid amphipods (Bousfield 1973, Lewis and Stoner 1983, Lewis 1984). Other studies have reported similar correlated temporal variations in peak plant growth and amphipod reproduction and abundance (Nelson 1980, Stoner 1980b).

Although biomass of sea grass in Cockle Bay seems to be an important factor influencing abundance of the benthic macrofaunal community, life cycle (including recruitment and reproduction) and predation may also directly or indirectly control benthic macrofaunal abundance. These factors may explain why amphipod abundance at station 2 increased in March 2000 when aboveground sea-grass biomass declined. For example, this could be due to the delayed movement of 
Ericthonius sp. A and Elasmopus antennatus, among common amphipods, to the sea grass following an increase in aboveground seagrass biomass. Alternatively there may have been a community shift from epibenthic sea-grass grazers to surface microalgal and/ or detritus feeders. Fong (1999) reported that amphipod diversity and abundance in the sea-grass beds in Thomson Bay, Western Australia, were affected by the recruitment and life cycle of amphipods. Generally patterns of distribution and abundance of benthic macrofauna are often complicated by unpredictable annual recruitment of young in the sea-grass beds (Collett et al. 1984, Edgar 1992).

Patterns of amphipod abundance in Cockle Bay are probably also related to local variations in the abundance of predators. Kwak and Klumpp (2004) demonstrated that the abundance of dominant fishes in the sea-grass beds of Cockle Bay was positively correlated with prey availability. For example, amphipods are an important prey item in the diet of many key predatory fishes (Sillago, Favonigobius, Letbrinus, and Pelates), and the abundance of Sillago maculata burrus and Favonigobius reichei, both carnivores that can feed heavily on amphipods, appears correlated with amphipod abundance. Carr and Adams (1973) recorded that fishes, which can feed heavily on amphipods in sea-grass beds in Florida, have been shown to have an impact on amphipod populations.

Decapods found in the sea-grass beds of Cockle Bay typically inhabited the leaves. The wide distribution and high abundance of groups such as Alpheus, Clibanarius, and Petalomera lateralis in Cockle Bay are explained by their life cycle, which is well adapted to the plant's annual cycle (Lorenti and Scipione 1990). Among miscellaneous groups, tanaids were dominated by Pagurapseudes, which were most abundant in August 2000 when sea-grass biomass was low but were absent in other months. Generally Pagurapseudes is a common genus in tropical areas, especially on coral reefs (Bacescu 1981). Hence we assume that the temporal variations of this species may be related to their movement from nearby coral reefs.

\section{ACKNOWLEDGMENTS}

We are grateful to Craig Humphrey of Australian Institutes of Marine Science for assistance with sampling and to Graham Edgar for his advice on sampling.

\section{Literature Cited}

Bacescu, M. 1981. Contribution to the knowledge of the Monokonophora (Crustacea, Tanaidacea) of the eastern Australian coral reefs. Rev. Roum. Biol. 26 (2): 111-120.

Bertness, M. D., S. D. Gaines, and M. E. Hay. 2001. Marine community ecology. Sinauer Assoc., Inc., Sunderland, Massachusetts.

Blaber, S. J. M., D. T. Brewer, D. Caeser, M. Connell, D. Dennis, J. Glaister, N. Gribble, B. J. Hill, B. Long, D. A. Milton, R. Pithcher, I. R. Poiner, J. Salini, M. Thomas, S. Veronise, Y. Wang, and T. Wassenberg. 1993. The effects of prawn trawling in the far northern section of the Great Barrier Reef: Final report to GBRMPA on 1991-1992 research. CSIRO Division of Fisheries, June 1993, Queensland.

Bousfield, E. L. 1973. Shallow-water gammaridean Amphipoda of New England. Cornell University Press, Ithaca, New York.

Carr, W. E. S., and C. A. Adams. 1973. Food habits of juvenile marine fishes occupying seagrass beds in the estuarine zone near Crystal River, Florida. Trans. Am. Fish. Soc. 102:511-540.

Coles, R. G., W. J. Lee-Long, S. A. Helmke, R. E. Bennet, K. J. Miller, and K. J. Derbyshire. 1992. Seagrass beds and juvenile prawn and fish nursery grounds. Cairns to Bowen. Information Service, Department Primary Industries Qld., 192012, Brisbane, Australia.

Collett, L. C., P. A. Hutchings, P. J. Gibbs, and A. J. Collins. 1984. A comparative study of the macro-benthic fauna of Posidonia australis seagrass meadows in New South Wales. Aquat. Bot. 18:111-134.

De Troch, M., S. Gurdebeke, F. Fiers, and 
M. Vinex. 2001. Zonation and structuring factors of meiofauna communities in a tropical seagrass bed. J. Sea Res. 45:4561.

Duarte, C. M., J. Terrados, N. S. R. Agawin, M. D. Fortes, S. Bach, and W. J. Kenworth. 1997. Response of a mixed Philippine seagrass meadow to experimental burial. Mar. Ecol. Prog. Ser. 147:285294.

Edgar, G. 1990. The influence of plant structure on the species richness, biomass and secondary production of macrofaunal assemblages associated with Western Australian seagrass beds. J. Exp. Mar. Biol. Ecol. 137:215-240.

-1992. Patterns of colonization of mobile epifauna in a Western Australian seagrass bed. J. Exp. Mar. Biol. Ecol. 157:225-264.

-1 1994. Observations on the sizestructure of the macrofaunal assemblages. J. Exp. Mar. Biol. Ecol. 176:227-243.

Edgar, G. J., and N. S. Barrett. 2002. Benthic macrofauna in Tasmanian estuaries: Scales of distribution and relationships with environmental variables. J. Exp. Mar. Biol. Ecol. 270:1-24.

Edgar, G. J., C. Shaw, G. F. Watson, and L. S. Hammond. 1994. Comparisons of the species richness, size-structure and production of benthic vegetated and unvegetated habitats in Western Port, Victoria. J. Exp. Mar. Biol. Ecol. 176:201226.

Fisher, R. 2003. Spatial and temporal variations in nematode assemblages in tropical seagrass sediments. Hydrobiologia 493:43-63.

Fong, T. C. W. 1999. The relationship between seagrass canopy, detritus accumulation and amphipod abundance in Thomson Bay, Rottnest Island. Pages 247-253 in F. E. Wells, D. I. Walker, H. Kirkman, and R. Lethbridge, eds. The seagrass flora and fauna of Rottnest Island, Western Australia. Western Australian Museum, Perth.

Heijs, F. M. L. 1985. Some structural and functional aspects of the epiphytic component of four seagrass species (Cymodoceoi- deae) from Papua New Guinea. Aquat. Bot. 23:225-248.

Hutchings, P. A. 1982. The fauna of Australian seagrass beds. Proc. Linn. Soc. N. S. W. 106:181-200.

Hutchings, P. A., F. E. Wells, D. I. Walker, and G. A. Kendrick. 1991. Seagrass, sediment and infauna: A comparison of Posidonia australis, Posidonia sinuosa and Amphibolis antarctica in Princess Royal Harbour, south-western Australia. II. Distribution, composition and abundance of macrofauna. Pages 611-633 in F. E. Wells, D. I. Walker, H. Kirkman, and R. Lethbridge, eds. Proceedings of the 3rd International Marine Biological Workshop: The Marine Flora and Fauna of Albany, Western Australia. Western Australian Museum, Perth.

Klumpp, D. W., R. K. Howard, and D. A. Pollard. 1989. Trophodynamics and nutritional ecology of seagrass communities. Pages 394-437 in A. W. D. Larkum, A. J. McComb, and S. A. Shepherd, eds. Biology of seagrasses: A treatise on the biology of seagrasses with special reference to the Australian region. Elsevier, Amsterdam.

Klumpp, D. W., J. S. Salita-Espinosa, and M. D. Fortes. 1992. The role of epiphytic periphyton and macroinvertebrate grazers in the trophic flux of a tropical seagrass community. Aquat. Bot. 43:327-349.

- 1993. Feeding ecology and trophic role of sea urchins in a tropical seagrass community. Aquat. Bot. 45:205-229.

Knowles, L. L., and S. S. Bell. 1998. The influence of habitat structure in faunalhabitat associations in a Tampa Bay seagrass system, Florida. Bull. Mar. Sci. 62 (3): 781-794.

Kwak, S. N. 1997. Biotic communities and feeding ecology of fish in Zostera marina beds off Dae Island in Kwangyang Bay. Ph.D. thesis, Pukyong National University, Pusan, Korea.

Kwak, S. N., and D. W. Klumpp. 2004. Temporal variation in species composition and abundance of fish and decapods in Cockle Bay, North Queensland, Australia. Aquat. Bot. 78:119-134. 
Lewis, F. G., III. 1984. Distribution of macrobenthic crustaceans associated with Thalassia, Halodule and bare substrata. Mar. Ecol. Prog. Ser. 19:101-113.

Lewis, F. G., III, and A. W. Stoner. 1983. Distribution of macrofauna within seagrass beds: An explanation for patterns of abundance. Bull. Mar. Sci. 33 (2): 296-304.

Loneragan, N. R., R. A. Kenyon, M. D. E. Haywood, and D. J. Staples. 1994. Population dynamics of juvenile tiger prawns (Penaeus esculentus and P. semisulcatus) in seagrass habitats of the western Gulf of Carpentaria, Australia. Mar. Biol. (Berl.) 119:133-143.

Long, B. G., I. R. Poiner, and T. Wassenberg. 1995. Distribution, biomass and community structure of megabenthos of the Gulf of Carpentaria, Australia. Mar. Ecol. Prog. Ser. 129:127-139.

Lorenti, M., and M. B. Scipione. 1990. Relationships between trophic structure and diel migrations of isopods and amphipods in a Posidonia oceanica bed of the island of Ischia (Gulf of Naples, Italy). Rapp. P.-V. Reun. Comm. Int. Explor. Sci. Mer Mediterr. Monaco 32 (1): 17-23.

Mazzella, L., and R. S. Alberte. 1986. Light adaptation and the role of autotrophic epiphytes in primary production of the temperate seagrass Zostera marina L. J. Exp. Mar. Biol. Ecol. 100:165-180.

Mukai, H., T. Suzuki, and S. Nojima. 1999. Morphological implications of seagrass substratum for mobile epifauna community, Rottnest, Western Australia. Pages 255-274 in F. E. Wells, D. I. Walker, H. Kirkman, and R. Lethbridge, eds. The seagrass flora and fauna of Rottnest Island, Western Australia. Western Australian Museum, Perth.

Nelson, W. G. 1980. A comparative study of amphipods in seagrasses from Florida to Nova Scotia. Bull. Mar. Sci. 30:80-89.

Orth, R. J., J. K. L. Heck, and J. v. Montfrans. 1984. Faunal communities in seagrass beds: A review of the influence of plant structure and prey characteristics on predator-prey relationships. Estuaries 7 (4A): $339-350$.

Pielou, E. C. 1969. An introduction to math- ematical ecology. John Wiley and Sons, New York.

Rainer, S. F., and R. Fitzhardinge. 1981. Benthic communities in an estuary with periodic deoxygenation. Aust. J. Mar. Freshwater Res. 32:227-243.

Schneider, F. I., and K. H. Mann. 1991. Species specific relationships of invertebrates to vegetation in a seagrass bed. I. Correlational studies. J. Exp. Mar. Biol. Ecol. 145:101-117.

Sfriso, A., T. Birkemeyer, and P. F. Ghetti. 2001. Benthic macrofauna changes in areas of Venice lagoon populated by seagrass or seaweeds. Mar. Environ. Res. 52:323-349.

Shannon, C. E., and W. Weaver. 1949. The mathematical theory of communication. University of Illinois Press, Urbana.

Sheridan, P. 1997. Benthos of adjacent mangrove, seagrass and non-vegetated habitats in Rookery Bay, Florida. Estuarine Coastal Shelf Sci. 44:455-469.

Somerfield, P. J., S. Yodnarasri, and C. Aryuthaka. 2002. Relationships between seagrass biodiversity and infaunal communities: Implications for studies of biodiversity effects. Mar. Ecol. Prog. Ser. 237:97-109.

Stoner, A. W. 1980a. Perception and choice of substratum by epifaunal amphipods associated with seagrasses. Mar. Ecol. Prog. Ser. 3:105-111.

- 1980b. Abundance, reproductive seasonality, and habitat preferences of amphipod crustaceans in seagrass meadows of Apalachee Bay, Florida. Contrib. Mar. Sci. 23:63-77.

1983. Distributional ecology of amphipods and tanaidaceans associated with three seagrass species. J. Crustacean Biol. 3 (4): 505-518.

Valentine, J. F., K. L. Heck, P. Harper, and M. Beck. 1994. Effects of bioturbation in controlling turtlegrass (Thalassia testudinum Banks ex Konig) abundance: Evidence from field enclosures and observations in the northern Gulf of Mexico. J. Exp. Mar. Biol. Ecol. 178:181-192.

Valentine, J. F., K. L. Heck, J. Busby, and D. Webb. 1997. Experimental evidence that herbivory increases shoot density and 
productivity in a subtropical turtlegrass (Thalassia testudinum) meadow. Oecologia (Berl.) 112:193-200.

Ward, T. J., and S. F. Rainer. 1988. Decapod crustaceans of the North West Shelf, a tropical continental shelf of northwestern Australia. Aust. J. Mar. Freshwater Res. 39:751-765.

Williams, S. L., and K. L. Heck. 2001. Seagrass community ecology. Pages 317-337 in M. D. Bertness, S. D. Gaines, and M. E. Hay, eds. Marine community ecology. Sinauer Assoc., Inc., Sunderland, Massachusetts.

Young, D. K., and M. W. Young. 1977. Community structure of the macrobenthos associated with seagrass of the Indian River, Florida. Pages 359-381 in B. C.
Coull, ed. Ecology of marine benthos. University of South Carolina Press, Columbia.

. 1978. Regulation of species densities of seagrass-associated macrobenthos: Evidence from field experiments in the Indian River Estuary, Florida. J. Mar. Res. 36:569-593.

Young, D. K., M. A. Buzas, and M. W. Young. 1976. Species densities of macrobenthos associated with seagrasses: A field experimental study of predation. J. Mar. Res. 34:577-592.

Zimmerman, R. J. 1978. The feeding habits and trophic position of dominant gammaridean amphipods in a Caribbean seagrass community. Ph.D. thesis, Puerto Rico University, Mayaguez. 